\title{
THE IMPACT OF THE HUMAN RIGHTS CONVENTION ON THE DEVELOPMENT OF THE ADMINISTRATIVE JUDICIARY OF UKRAINE
}

\author{
Yana Sandul and Andriy Strelnykov
}

Summary: 1. - Background of the Emergence of Administrative Proceedings in Ukraine. - 2. Problems of Determining the Body of Power and the State and its Bodies as Parties to the Case. - 3. Features of the Exercise of the Right to a Fair Trial in Administrative Proceedings. - 3.1. Access to Court and the Principle of Equality of Parties. - 3.2. Orality and Openness of Administrative Proceedings. - 3.3. The Aversarial System and the Right of the Court to Establish the Circumstances of the Administrative Case. - 4. Concluding Remarks.

To cite this note: Ya Sandul, A Strelnykov 'The Impact of the Human Rights Convention on the Development of the Administrative Judiciary of Ukraine' 2021 1(9) Access to Justice in Eastern Europe 223-231. D0I: 10.33327/AJEE-184.1-n000054

To link to this note: https://doi.org/10.33327/AJEE-18-4.1-n000054

Submitted on 11 0ct 2020 / Revised 21 Dec 2021 / Revised 1 Dec 2021 / Approved 22 Feb 2021/ Published online: 01 Mar $2021 \quad$ View data

Submit your article to Access to Justice in Eastern Europe http://ajee-journal.com/submissions

\section{ACKOWLEDGMENTS}

Authors would like to express their gratitude to the reviewers for their help and to the English editor.

\section{CONFLICT OF INTEREST}

The authors have declared that no conflict of interest or competing interests exist.

\section{CONTRIBUTORS}

Both the coauthors contributed equally to the intellectual discussion underlying this paper, case law exploration and writing the draft and responsible for the final version of the article. 


\title{
THE IMPACT OF THE HUMAN RIGHTS CONVENTION ON THE DEVELOPMENT OF THE ADMINISTRATIVE JUDICIARY OF UKRAINE
}

\author{
Sandul Yana \\ $\mathrm{PhD}$ (Law), Assoc. Prof. of the Department \\ of Administrative and Financial Law, \\ National University ‘Odessa Law Academy', Ukraine \\ Strelnykov Andriy \\ $\mathrm{PhD}$ (Law), Assoc. Prof. of the Department \\ of Administrative and Financial Law, \\ National University ‘Odessa Law Academy’, Ukraine
}

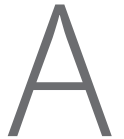

bstract The administration of justice on the basis of a fair trial is not an easy task, as both parties to the dispute are usually certain of their rightness, which they are trying to prove to the court. If one of these parties is a state or its bodies, the judiciary can become a dangerous tool to influence any process in society. Specific cases against Ukraine show that high-ranking officials of all periods of power did not neglect the possibility of influencing the outcome of the case, pursuing goals not related to the administration of justice. The influence of the European Convention and the case law of the European Court of Human Rights has become decisive for Ukraine in the formation of a separate procedure for the administration of justice: administrative proceedings. Some aspects of its functioning are investigated in this work, in particular, the preconditions for the differentiation of administrative proceedings in Ukraine, the problem of defining the concept of the authorities and the state as a party to the case, the implementation of the right to a fair trial in administrative proceedings, access to court and the principle of the equality of parties; oral and open administrative proceedings; adversarial proceedings and the right of the court to establish the circumstances of the administrative case.

Keywords: administrative proceedings; the right to a fair trial; access to court; the principle of equality of parties; oral and open administrative proceedings; the right of the court to establish the circumstances of the administrative case.

\section{BACKGROUND OF THE EMERGENCE OF ADMINISTRATIVE PROCEEDINGS IN UKRAINE}

In the independent Ukrainian state, since 1991, the jurisdiction of general courts to resolve individual administrative complaints has gradually expanded. The Code of Civil Procedure of that time contained three main types of proceedings: action procedure, designed to consider and resolve disputes arising from civil relations, separate procedure, which mainly dealt with undisputed cases, as well as proceedings on administrative and legal relations, which included proceedings to consider specific categories of cases. In particular, chapter 31-A of the CPC of Ukraine, as amended on 31 October 1995, established the court to 
consider cases concerning violations of election law; on applications for the early termination of powers of the People's Deputy of Ukraine in case of non-fulfillment by him or her of requirements concerning the incompatibility of deputy activity with other types of activity; on complaints against actions of bodies and officials in connection with the imposition of administrative penalties; on complaints against decisions, actions or omissions of public authorities, local governments and officials; on complaints against decisions made regarding religious organizations; according to the prosecutor's statements on declaring the legal act illegal; on complaints against decisions, actions or inaction of the state executor or other official of the state executive service; on the recovery of arrears of taxes, the self-taxation of the rural population and state compulsory insurance, as well as other cases arising from administrative and legal relations, referred by law to the jurisdiction of the courts. ${ }^{1}$

Before 2004, which was marked by the adoption of the new Civil Procedure Code of Ukraine, this chapter was supplemented by various categories of cases, until in 2005 the Code of Administrative Procedure of Ukraine was adopted. ${ }^{2}$

It is worth mentioning that starting from the first steps of statehood in the Ukrainian lands in the early XX century, Ukraine has tried to introduce a model of administrative justice, similar to European models. It can be illustrated by Art. 158 of the Ukrainian Code of Administrative Procedure of 12 October $1927,{ }^{3}$ according to which important measures for the implementation of administrative acts could be challenged.

The deep understanding of the content of administrative proceedings and its differentiated consideration primarily in constitutional rule-making is evidenced, for example, by the current rule 58 of Chapter VII of the Constitution of the Ukrainian People's Republic of $1918,{ }^{4}$ as well as its concretization in the Law on the Abolition of the State Senate and the Introduction of the Supreme court, ${ }^{5}$ which provided for the existence not only of administrative proceedings as a specialized process, but also the relevant department, which, along with civil and criminal ones was a way of organizing the work of the court. The provisions of the alternative draft Constitution of the Ukrainian People's Republic, developed by O. Eichelman, ${ }^{6}$ among other things, defined in some detail certain aspects of the idea of administrative justice.

The preconditions for the introduction of administrative proceedings in Ukraine were formed gradually. The Constitution, adopted on 28 June 1996, ${ }^{7}$ established the principles of the division of state power of Ukraine into legislative, executive and judicial. Art. 55 of the Constitution of Ukraine declares that everyone is guaranteed the right to appeal against decisions, actions or inaction of public authorities, local governments and officials in court.

The concept of judicial reform, approved by the Verkhovna Rada in 1992, ${ }^{8}$ provided for the gradual introduction of administrative justice: from the specialization of judges and the formation

1 Civil Procedural Code of Ukraine (as amended of 02 February 1996) Chapters 123- $288<$ https://zakon. rada.gov.ua/laws/show/1502-06/ed19960202\#Text> accessed 18 January 2021.

2 Code of Administrative Procedure of Ukraine <https://zakon.rada.gov.ua/laws/show/2747-15\#Text> accessed 18 January 2021.

3 V Verstiuk, O Boiko, R Pyrih et al (eds), Directory, Council of People's Ministers of the Ukrainian People's Republic 1918-1920: Documents and Materials, Vol 2 (Vydavnytstvo Oleny Telihy 2006).

$4 \quad$ Verstiuk (n 4).

$5 \quad$ Verstiuk (n 4).

6 O Eihelman, Draft constitution - the basic state laws of the Ukrainian People's Republic (Kyiv-Tarniv 1921).

7 The Constitution of Ukraine (of 28 June 1996).

8 Verkhovna Rada of Ukraine, 'Resolution 'On the Concept of Judicial and Legal Reform in Ukraine' (1992) 4 Vidomosti of the Verkhovna Rada of Ukraine. 
of specialized judicial boards to the creation of the hierarchy of administrative courts. ${ }^{9}$ The introduction of a system of administrative courts for the purpose of full-fledged judicial protection of the rights and freedoms of citizens in the sphere of executive power was also envisaged by the Concept of Administrative Reform in Ukraine, approved by the President of Ukraine in 1998. ${ }^{10}$

The first real step towards the establishment of administrative courts was taken during the so-called 'minor judicial reform' of 2001, when the law recommended that the Chairman of the Supreme Court of Ukraine and the Minister of Justice of Ukraine prepare and submit the establishment of Supreme Administrative Court to the President of Ukraine. ${ }^{11}$ However, this law did not provide for the peculiarities of the status of specialized courts, including administrative ones, as well as the characteristics of the system of these courts.

The next important step was the adoption on 7 February 2002 by the Verkhovna Rada of Ukraine of the Law of Ukraine 'On the Judiciary of Ukraine', which determined the place of administrative courts in the system of courts of general jurisdiction, thus dividing administrative courts into a subsystem of specialized courts.

On 6 July 2005, the Code of Administrative Procedure of Ukraine was adopted, ${ }^{12}$ which defined the powers of administrative courts to hear cases of administrative jurisdiction, the procedure for appealing to administrative courts and the procedure for conducting administrative proceedings.

The Code of Administrative Procedure of Ukraine (CAP) defines the powers of administrative courts regarding the consideration of cases of administrative jurisdiction, the procedure for appealing to administrative courts and the procedure for conducting administrative proceedings, namely, it consists of 391 articles, which are grouped into five sections.

The main task of administrative proceedings under Art. 2 of the CAP is a fair, impartial and timely resolution by the court of disputes in the field of public relations in order to effectively protect the rights, freedoms and interests of individuals, and the rights and interests of legal entities from violations by bodies of power. Thus, the most important question facing scholars and practitioners is the definition of the concept of the body of power. At the same time, this was significantly influenced by the provisions of the ECHR, as well as the practice of the ECtHR, which formed the basis of the concept of public authority in Ukraine. The second part of the work is devoted to this issue. The participation of such an entity is conditioned by the peculiarities of consideration of an administrative case in the light of the case law of the ECtHR and ensuring the right of a person to a fair trial. This issue is considered in the third part of our note. The study of these aspects made it possible to summarize certain conclusions at the end.

\section{PROBLEMS OF DETERMINING THE BODY OF POWER AND THE STATE AND ITS BODIES AS PARTIES TO THE CASE}

The main purpose of the separation of administrative proceedings in the justice system of Ukraine was to ensure the right of a person to a fair trial in disputes to which the state or the body of power is a party.

9 IB Koliushko, RO Kuibida, Administrative justice: European experience and proposals for Ukraine (Fakt 2003).

10 Decree of the President of Ukraine of 22 July 1998 'On measures to implement the Concept of Administrative Reform in Ukraine' [1998] 7 Vidomosti of the Verkhovna Rada of Ukraine.

11 Law of Ukraine of 21 June 2001 'On Amendments to the Law “On the Judiciary of Ukraine" [2001] 6 Bulletin of the Verkhovna Rada of Ukraine.

12 Code (n 2). 
The concept of 'public law dispute' is distinguished by defining a specific party of this kind of dispute, namely, a body of power.

Public law dispute is a dispute in which:

- at least one party performs public authority management functions, including the performance of delegated powers, and the dispute arose in connection with the performance or non-performance of these functions by such party; or

- at least one party provides administrative services under the law that authorizes or obliges exclusively the body of power to provide such services, and the dispute arose in connection with the provision or non-provision of such services by such party; or

- at least one party is the subject of an election or referendum process and the dispute has arisen in connection with the violation of its rights in such a process by the body of power or another person.

At the same time, the law does not provide for a list of such bodies of power or their powers, so they are separated as representatives of public service in state political positions, state collegial bodies, the professional activities of judges, prosecutors, the military service, alternative (non-military) service, other civil service, the patronage service in state bodies, the service in the authorities of the Autonomous Republic of Crimea, and in local selfgovernment bodies.

At the same time, such a definition does not give a complete, clear idea of the criteria for classifying a service as public. The scope of the current Law of Ukraine 'On Civil Service'13 has no clear boundaries. Therefore, the case law of the ECtHR provided an opportunity to identify several important criteria by which to differentiate public law disputes.

In particular, the continuity and professionalism of the body's performance of its powers is emphasized by the decision of the European Court of Human Rights in the case of Chuikin v. Ukraine, ${ }^{14}$ in which paragraph 1 of Art. 6 of the Convention was breached, as the case was closed in connection with the liquidation of a public body, thus depriving the applicant of access to a court without deciding the merits of the claim and allowing the State to avoid liability for the illegal actions of its body.

The decision of the European Court of Human Rights in the case of Agrocomplex v. Ukraine ${ }^{15}$ is also important in this respect. In this case, the ECtHR examined in detail the documentary evidence of various Ukrainian authorities that repeatedly interfered in the proceedings, openly and persistently, often at the request of the applicant's opponent. In particular, such requests included LyNOS's ${ }^{16}$ appeal to the First Vice-Speaker and the Speaker of Parliament, as well as to the Prime Minister and the President of Ukraine to intervene in the proceedings, as well as letters from these officials to the Chairman of the Supreme Court with orders to cancel or reconsider decisions made by the court earlier, to terminate the proceedings or simply to add requirements from LyNOS. At the same time, some Ukrainian officials even responded to some of these letters by providing reports on the status of the case, as well as by explaining the measures taken during the trial, and LyNOS openly thanked the President of Ukraine for his intervention, which was considered successful, suggesting that 'positive results speak for themselves'.

The ECtHR has repeatedly condemned attempts by non-judicial authorities to interfere in the proceeding, as this is a violation of an 'independent and impartial court' within the meaning

13 Law of Ukraine 'On Public Service' [2016] Vidomosti of the Verkhovna Rada 4/43<https://zakon.rada. gov.ua/laws/show/889-19\#Text> accessed 18 January 2021.

14 Chuykina v Ukraine (App no 28924/04) ECHR 13 January 2011.

15 Agrokompleks $v$ Ukraine (App no 23465/03) ECHR 06 October 2011. http://hudoc.echr.coe.int/ fre? $\mathrm{i}=001-106636$

16 LyNOS - the Lysychansk Oil Refinery, renamed LysychanskNaftoOrgSyntez (“LyNOS”). 
of Art. 6 Item 1 of the Convention, in particular in the well-known case of Sovtransavto Holding v. Ukraine ${ }^{17}$ and Agrotechservice v. Ukraine. ${ }^{18}$

Having regard to the fact that the case concerned the bankruptcy of the enterprise, which at that time was the largest oil refinery in Ukraine, and the State was the main shareholder, the attention paid by the State authorities to these lawsuits is quite natural. The violation was that these authorities, however, did not limit themselves to passive monitoring of the proceedings in the context of their extrajudicial efforts to overcome the crisis in LyNOS, but brazenly interfered with the trial.

At the same time, in the cases of Melnyk $v$. Ukraine ${ }^{19}$ and Karuna v. Ukraine ${ }^{20}$ the ECtHR noted that it was a well-established practice to apply to Ukraine all the guarantees enshrined in Art. 6 before the court of cassation in both civil and administrative cases despite their Ukrainian classification.

\section{FEATURES OF THE EXERCISE OF THE RIGHT TO A FAIR TRIAL IN ADMINISTRATIVE PROCEEDINGS}

Certain provisions of the CAP were adopted under the influence of the provisions of the European Convention and in accordance with the practice of the ECtHR. Among them, for example, are:

1) the impartiality of the court considering the administrative case (Decision in the case Belukha v. Ukraine); ${ }^{21}$

2) the requirement that the body of power observe the principle of equality before the law, preventing unfair discrimination by establishing the principle of equality of the parties to the proceedings (Nadtochiy v. Ukraine, ${ }^{22}$ Decision in the case Bendersky v. Ukraine);23

3 ) the requirement for the subject of power to comply with the principle of proportionality (Decision in the case of Volovik v. Ukraine) ${ }^{24}$. More details about these cases are given below.

\subsection{Access to Court and the Principle of the Equality of Parties}

Access to justice is a cornerstone of the rule of law and access to justice in general in a democratic state governed by the rule of law. However, the right of access to a court may be limited, but at the same time it must have an aim and be proportionate between the means used and the objectives achieved.

In its judgment in Volovik v. Ukraine, ${ }^{25}$ the Court noted that the provisions of the CPC of 1963 provided for a 'filter' of appeals against decisions and rulings of the court of first instance by the same court that had the right to decide the admissibility of the complaint, although this

\footnotetext{
17 Sovtransavto Holding $v$ Ukraine (App No 48553/99) ECHR 2002-VII para 80.

18 Agrotehservis v Ukraine ((App no 62608/00) ECHR 19 October 2004

19 Melnyk $v$ Ukraine (App no 23436/03) ECHR 28 March 2006 para 25.

20 Karuna $v$ Ukraine, decision on application approval (App no 43788/05) ECHR 3 April 2007.

21 Biluha v Ukraine (App no 33949/02) ECHR 9 November 2006.

22 Nadtochiy v Ukraine (App no 7460/03) ECHR 15 May 2008.

23 Benderskiy v Ukraine (App no 22750/02) ECHR 15 November 2007).

24 Volovik v Ukraine (App no 15123/03) ECHR 6 December 2007.

25 Volovik v Ukraine (n 23).
} 
procedure was probably designed to ensure the proper administration of justice. However, regarding the procedural requirements in force at the time of the proceedings and the manner in which they were applied in the applicant's case, the Court concludes that the means applied were not proportionate to the purpose pursued. Thus, the Court considers that the courts of first instance have uncontrolled power to decide whether an appeal against a decision of the same court may be lodged with a higher court. Such a situation is likely to result in the appeal never being referred to a higher court, as happened in the applicant's case.

The principle of equality has been repeatedly applied by the ECtHR in cases concerning Ukraine. But in cases of administrative proceedings, it becomes especially important. For example, in the case of Nadtochiy v. Ukraine, ${ }^{26}$ The ECtHR noted that during the administrative proceedings against the applicant, the applicant was serving a sentence in a place of imprisonment and did not take part in the administrative proceedings. Of note is there being no evidence that he had received summons or notices. Due to his being in prison, he was virtually unable to fulfill his obligation to remove the car. However, the domestic authorities did not analyze these circumstances on their own initiative and did not allow the applicant to raise the issue. Instead, the domestic authorities reclassified the applicant's actions to another offence: the loss of property under customs control. Thus, the Court found a breach of important procedural guarantees, in particular the principle of equality.

In Benderskiy v. Ukraine, ${ }^{27}$ the ECtHR states that in his statements of claim the applicant referred to the doctors' testimony, asking the judges to decide whether there was a specific circumstance in the case, but the courts did not satisfy them, noting simply that there could be 'other means of introducing a foreign body into this organ, even if they are unlikely'. The ECtHR considers that there were no obstacles to examining the case in more detail in the direction indicated by the applicant, particularly given that the expert medical report was incomplete and did not contain relevant information. Consequently, the right to a fair trial within the meaning of Art. 6 para 1 of the Convention was not guaranteed.

\subsection{Orality and the Openness of Administrative Proceedings}

In the decision in the case of Luchaninov v. Ukraine, ${ }^{28}$ the Court notes that, although the public's access to the trial in question was not formally restricted, the circumstances in which it took place were a clear obstacle to its publicity, particularly as the trial took place in a restricted dispensary and the court did not allow persons other than the participants in the proceedings to remain in or enter the trial chamber. Also, the information on the date and place of the hearing was not provided.

\subsection{The Adversarial System and the Right of the Court to Establish the Circumstances of the Administrative Case}

The peculiarity of administrative proceedings regarding the court's ability to establish circumstances in an administrative case on the basis not only of evidence collected by the parties or on their initiative, but also of evidence collected by the court on its own initiative (paragraph 5 of Art. 11, paragraph 2 of Art. 69, paragraph 5 of Art. 71 of the CAP).

At the same time, in the judgment in Plakhteyev and Plakhteyeva v. Ukraine ${ }^{29}$ the Court notes that the applicants' claim mentioned State Tax Administration as another defendant and it

\footnotetext{
$26 \quad$ Nadtochiy v Ukraine (n 21).

27 Benderskiy v Ukraine (App no 22750/02) ECHR 15 November 2007.

28 Luchaninova $v$ Ukraine (App no 16347/02) ECHR 9 June 2011.

29 Plakhteyev and Plakhteyeva v Ukraine (App no 20347/03) ECHR 12 March 2009.
} 
was alleged that: (i) they had not been able to obtain the return of the car and the wheat from the State Tax Administration after the court had ruled in the administrative case, that is, when there were no legal grounds for further maintenance of their property; and (ii) that the property was significantly damaged during the State Tax Administration's disposal. These complaints had nothing to do with the district court and were clearly addressed to the State Tax Administration. However, the domestic courts did not respond to this part of the action and did not explain why it could not be considered in an adversarial trial. In particular, the Supreme Court dismissed the applicants' cassation appeal without giving any explanation.

\section{CONCLUDING REMARKS}

Administrative proceedings are part of the justice system of the state, thus ensuring the realization of the right of a person to the protection of their rights, if the party to the case is the state or its bodies.

The need to further develop the administrative justice of Ukraine is primarily due to the fact that the universal provisions of civil procedure may not fully ensure the realization of the right to a fair trial, as a party to the case is the state or its body. State bodies representing branches of government other than the judiciary can influence the course of proceedings (this is notably illustrated in the case of Agrocomplex v. Ukraine), so additional guarantees to ensure the protection of the rights of the average person are needed. Specifically, it is extremely important to ensure access to justice and the principle of equality of parties.

At the same time, the problems of determining the subject of power and the state as a party to the case can be solved through the application of ECtHR practice, particularly through such features of the right to a fair trial in administrative proceedings as the openness and the publicity of the trial, the court's obligation to establish the circumstances of the case officially, etc. The court, as the main body resolving the administrative cases, should play a more active role in establishing the circumstances of the case in order to ensure the effective protection of the rights of individuals.

\section{CONTRIBUTORS}

Dr. Sandul Yana is an associate professor of the Department of Administrative and Financial Law, National University 'Odessa Law Academy', Ukraine

ya.sandul@gmail.com

0000-0002-6823-7990

Dr. Strelnykov Andriy is an associate professor of the Department of Administrative and Financial Law, National University 'Odessa Law Academy', Ukraine

sav2220@gmail.com

0000-0002-7975-5611 


\section{REFERENCES}

Civil Procedural Code of Ukraine (as amended of 02 February 1996) Chapters 123- $288<$ https:// zakon.rada.gov.ua/laws/show/1502-06/ed19960202\#Text> accessed 18 January 2021.

Code of Administrative Procedure of Ukraine <https://zakon.rada.gov.ua/laws/show/ 2747-15\#Text> accessed 18 January 2021.

Koliushko IB, Kuibida RO, Administratyvna Yustytsiia Yevropeiskyi Dosvid I Propozytsii Dlia Ukrainy [Administrative justice: European experience and proposals for Ukraine] (Fakt 2003).

Eihelman O, Proekt Konstytutsii - Osnovnykh Derzhavnykh Zakoniv Ukrainskoi Narodnoi Respubliky [Draft constitution - the basic state laws of the Ukrainian People's Republic] (Kyiv-Tarniv 1921).

Verstiuk V, Boiko O, Pyrih R et al (eds), Dyrektoriia, Rada Narodnykh Ministriv Ukrainskoi Narodnoi Respubliky 1918-1920 Dokumenty I Materialy [Directory, Council of People's Ministers of the Ukrainian People's Republic 1918-1920: Documents and Materials], Vol 2 (Vydavnytstvo Oleny Telihy 2006). 